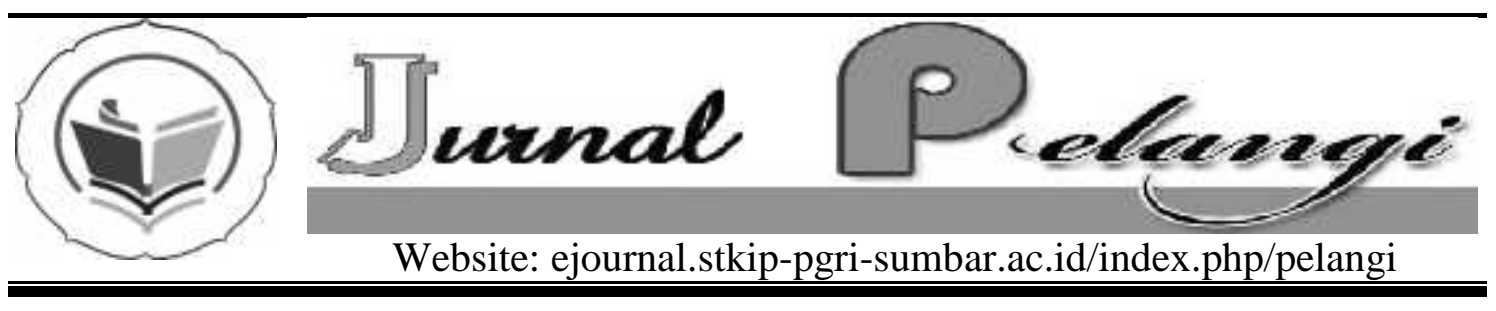

\title{
PEMBUATAN MOCAF (MODIFIED CASSAFA FLOUR) DENGAN PROSES FERMENTASI MENGGUNAKAN BEBERAPA JENIS RAGI
}

\author{
Erismar Amri ${ }^{1)}$, Putri Pratiwi ${ }^{2)}$ \\ ${ }^{1)}$ Program Studi Pendidikan Biologi STKIP PGRI Sumatera Barat \\ ${ }^{2)}$ Program Studi Pendidikan Bahasa Inggris STKIP PGRI Sumatera Barat \\ 1)erismar_amri@yahoo.co.id
}

\section{INFO ARTIKEL}

Diterima : 30/04/2014

Disetujui : 30/05/2014

\section{Kata Kunci:}

Fermentasi, mocaf,

ragi, singkong

\section{Keywords:}

Cassava,

Mocaf,

Fermentation,

Yeast

\begin{abstract}
Abstrak
Singkong merupakan tanaman tropis, produktif dan mudah dibudidayakan sehingga sangat diharapkan dapat menjadi salah satu solusi untuk meningkatkan ketahanan pangan nasional Indonesia. Mocaf merupakan produk tepung hasil fermentasi singkong menggunakan mikroorganisme. Mocaf ini diharapkan dapat mengganti penggunaan tepung terigu yang kebutuhannya semakin meningkat, sementara budidaya gandum sebagai bahan mentahnya tidak cocok dengan iklim Indonesia. Pada penelitian ini, digunakan beberapa macam ragi untuk memproduksi mocaf, diantanya ragi makanan merk Fermipan, Saf-Instan, ragi tempe raprima, ragi tapai dan ragi roti tanpa merk dan dilihat pengaruh perendaman singkong dengan garam sebelum proses fermentasi, terhadap nutrisi mocaf yang dihasilkan. Penelitian ini bertujuan untuk mengetahui jenis ragi dan proses fermentasi yang paling baik dalam meningkatkan kualitas nutrisi mocaf. Mocaf terbaik yang dihasilkan pada penelitian ini adalah mocaf yang dibuat dari fermentasi menggunakan ragi tape yang diawali perendaman dengan garam, karena menghasilkan mocaf dengan kadar protein yang paling tinggi yaitu $40.860 \%$, dengan kadar air rendah $6.640 \%$.
\end{abstract}

Abstract
Cassava is tropical plants, productive and easily cultivated so
it is expected to be one of the solutions to improve Indonesia's
national food security. Mocaf is fermented cassava flour
products using microorganisms. Mocaf is expected to replace
the use of wheat flour which its necessity is escalated through
the ages, while the area of wheat as a raw material is not fitted
the climate of Indonesia. This research performed some sort of
branded food yeast for producing Mocaf, taken for instance
Fermipan, Saf-Instant yeast, tempe raprima yeast, tapai yeast,


and unbranded bread yeast. It also would be analyzed the effect of soaking cassava with salt before fermentation, to nutrients generated by Mocaf. The objective of this research was knowing the types of yeast and fermentation process that is best in improving the nutritional quality of Mocaf. The best produced Mocaf in this research was made from fermented Mocaf using tapai yeast which was soaked with salt. It produced the highest level of protein i.e $40.860 \%$, with low water levels i.e $6.640 \%$.

\section{PENDAHULUAN}

Pangan merupakan identitas suatu bangsa. Itulah sebabnya kemandirian pangan merupakan hal yang sangat krusial bagi suatu negara karena kemandirian pangan tidak hanya berkaitan dengan pemenuhan kebutuhan dasar dari rakyat, tetapi juga dengan keberlanjutan pertumbuhan ekonomi (Kusumawardhani, 2012)

Diversifikasi pangan untuk memperkuat ketahanan nasional perlu lebih digalakkan oleh pemerintah. Langkah tersebut dilakukan guna mengurangi ketergantungan bahan pangan pokok beras. Masyarakat pun perlu menyadari bahwa bahan pangan lain, seperti jagung, ubi kayu, sagu, dan berbagai umbi lainnya dapat menjadi bahan makanan pokok.

Melihat pertumbuhan industri makanan berbahan baku terigu semakin berkembang pesat, maka terigu menjadi komoditas yang vital. Untuk mengatasi ketergantungan tepung terigu impor, kita harus melakukan diversifikasi tanaman pangan. Singkong merupakan tanaman tropis, produktif, dan mudah dibudidayakan sehingga sangat cocok dijadikan solusi untuk mengembangkan teknologi proses produksi tepung mocaf (modified cassava flour) (Salim, 2011).

Tepung mocaf merupakan tepung yang dibuat dari singkong yang difermentasi dengan mikroba. Beberapa mikroba yang sudah digunakan untuk menghasilkan tepung mocaf antara lain
Acetobacter xylinum (Salim, 2011), Rhizopus oryzae dan Saccharomyces cerevisae (Aida, et.al., 2012), serta Lactobacillus casei (Darmawan, Andreas, Jos, dan Sumardiono, 2013).

Penggunaan mocaf sebagai tepung alternatif pengganti terigu dalam membuat berbagai produk pangan telah banyak dilakukan, seperti dalam pembuatan mie basah dan mie kering (Rosmeri dan Monica, 2013) dan mie telur (Sukoco, 2013). Selain itu, mocaf juga sudah digunakan untuk membuat beras analog (Dewi, 2012) dan roti (Yenrina, Surya dan Putri, 2013). Namun masih terdapat kekurangan pada mocaf ini, antara lain belum bisa menggantikan tepung terigu atau beras secara sempurna karena masih berbeda rasa dan aromanya sehingga dalam penggunaannya masih harus dicampur dengan tepung terigu ataupun beras dengan kadar pencampuran tertentu. Oleh karena itu, perlu dilakukan penelitian untuk mencari mikroba yang efektif membantu proses fermentasi singkong, sehingga didapatka mocaf, yang secara fisik maupun kimia mirip dengan tepung terigu. Pada penelitian ini dilakukan pembuatan mocaf (modified cassava flour) dengan proses fermentasi menggunakan dua perlakuan yang berbeda yaitu perendaman dengan garam dan tanpa garam.

Tujuan penelitian ini adalah untuk mengetahui jenis ragi yang cocok untuk pembuatan mocaf dengan kandungan nutrisi yang baik dan untuk mengetahui 
hasil proses fermentasi terbaik yang didahului perendaman dengan garam atau tanpa perendaman.

\section{BAHAN DAN METODE}

\section{Bahan}

Bahan yang digunakan dalam penelitian ini adalah ubi kayu segar dari Bukittinggi-Agam, dikupas dan dipotong menjadi chip, garam dapur merk Supra-Salt dengan kandungan $\mathrm{NaCl} 99.25 \%$ w, lima jenis ragi makanan merk Fermipan, Saf-Instan, ragi tempe raprima, ragi tapai dan ragi roti tanpa merk yang dibeli di Pasar Raya Padang, dan aquadest steril.

\section{Persiapan bahan}

Persiapan bahan baku dimulai dari ubi kayu segar dibersihkan dari tanah dan kotoran dengan cara dicuci dalam keadaan belum terkupas. Untuk sekali percobaan dibutuhkan ubi kayu sekitar $1.5-2 \mathrm{~kg}$ untuk menghasilkan ubi kayu sawut/chip seberat $1 \mathrm{~kg}$.

Setelah ubi kayu bersih dari kotoran/tanah liat, dilakukan pengupasan ubi kayu dari kulitnya dengan menggunakan pisau biasa, setelah itu langsung direndam dalam air untuk menjaga warna ubi kayu tidak kecoklatan. Semua ubi kayu yang telah dikupas dan dicuci bersih, dirawut dengan cara memotongnya setebal 1-2 $\mathrm{mm}$ menggunakan alat pemotong ubi. Untuk satu kali percobaan dipakai ubi kayu sawut/chip seberat $1 \mathrm{~kg}$.

\section{Tahap fermentasi}

Tahap fermentasi dilakukan dengan dua perlakuan. Perlakuan pertama, sawut direndam dahulu dalam larutan garam dapur 5\%, selama 6 jam, perlakuan kedua, tidak dilakukan perendaman dengan garam. Sawut difermentasi menggunakan lima jenis ragi makanan merk Fermipan, Saf-Instan, ragi tempe raprima, ragi tapai dan ragi roti tanpa merk dengan konsentrasi $0,5 \%$, selama 3 hari.

\section{Tahap Pengeringan}

Setelah perendaman selesai sesuai dengan variabel, sawut ditiriskan dahulu untuk mengurangi kadar air sebelum dikeringkan. Sawut kemudian dikeringkan di dalam oven dengan suhu $40^{\circ} \mathrm{C}$ selama 1-2 hari sampai kering.

\section{Tahap Penepungan}

Sawut kering yang dihasilkan kemudian dihaluskan hingga membentuk tepung menggunakan blender. Setelah terbentuk tepung, agar diperoleh ukuran butiran tepung yang seragam, maka dilakukan pengayakan.

\section{Parameter yang diuji}

Parameter yang dianalisis yaitu kadar protein, kadar lemak, kadar abu, kadar air dan kadar serat kasar dan penghitungan kadar. Data yang didapatkan dianalisis menggunakan analisis sidik ragam, anova (analisys of variance) dan uji lanjut BNT (Beda Nyata Terkecil).

\section{Analisis Kandungan Nutrisi Mocaf Kadar protein (SNI 01-2973-1992)}

Sampel ditimbang (timbangan Analytical balance 230 Denver) sebanyak 1-2 g, dimasukkan ke dalam labu Kjeldahl flask Duran $100 \mathrm{ml}$, lalu ditambahkan $10 \mathrm{~g}$ campuran selen $(4 \mathrm{~g}$ selen $3 \mathrm{~g} \mathrm{CaSPO}_{4}$ dan $190 \mathrm{~g} \mathrm{Na}_{2} \mathrm{SO}_{4}$ ) dan $30 \mathrm{ml} \mathrm{H}_{2} \mathrm{SO}_{4}$ pekat teknis. Mulamula dipanaskan dengan kompor destruksi Gerhardt KI9/16 Germany pada nyala kecil (dalam ruang asam) sambil digoyang-goyangkan. Sesudah 510 menit api dipesarkan dan terus dipanaskan hingga warna cairan menjadi hijau jernih. Sesudah didinginkan, diencerkan dengan 250-300 $\mathrm{ml}$ air dan dipindahkan ke dalam labu didih dari 
$500 \mathrm{ml}$ yang di dalamnya telah ditambahkan beberapa butir batu didih. Ditambahkan $120 \mathrm{ml} \mathrm{NaOH} \mathrm{30 \%} \mathrm{dan}$ segera disambungkan dengan alat penyuling Distilation apparatus Gerhardt KI 9/16 Germany dan disuling hingga $2 / 3$ dari cairan tersuling. Sulingan yang terjadi diterima dalam $\mathrm{H}_{2} \mathrm{SO}_{4} \quad 0.25 \quad \mathrm{~N}$ berlebih. Akhirnya kelebihan $\mathrm{H}_{2} \mathrm{SO}_{4}$ dititrasi kembali $\begin{array}{llll}\text { dengan } & \mathrm{NaOH} & 0.5 & \mathrm{~N}\end{array}$ (indicator mengsel).

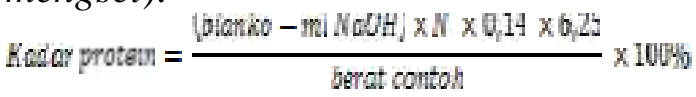

\section{Kadar lemak (SNI 01-2973-1992)}

Sampel ditimbang (timbangan Analytical balance 230 Denver) sebanyak 1-2 g dengan teliti, dimasukkan ke dalam piala, lalu ditambah $30 \mathrm{ml} \mathrm{HCl} \mathrm{25 \%} \mathrm{dan} 20 \mathrm{ml}$ air dan beberapa butir batu didih. Lalu ditutup dengan kaca arloji dan dipanaskan sampai mengarang (15 menit). Kemudian panas-panas disaring dan zat padatan yang terkandung di dalamnya dimasukkan ke dalam kertas saring pembungkus (Huls) diseduh dengan eter minyak tanah selama 2-3 jam dengan mempergunakan alat soklet Gerhardt IPEV 16 Germany. Sesudah itu eter disulingkan dan seduhan (lemak) dikeringkan lebih dahulu dengan alat peniup, kemudian dengan alat pengering listrik selama 0.5-1 jam pada suhu 102$105^{\circ} \mathrm{C}$, ditimbang hingga bobot tetap. Bobot seduhan adalah jumlah lemak.

Kadar lemak $=\frac{\text { bobot seduhan }}{\text { bobot contch }} \times 100 \%$

\section{Kadar abu (SNI 01-2973-1992)}

Sampel ditimbang (timbangan Analytical balance 230 Denver) 5-10 g, dimasukkan ke dalam cawan yang telah diketahui bobotnya. Mula-mula dipanaskan dengan Furnace digital Carbolite pada nyala kecil, lalu dengan nyala besar hingga abunya menjadi putih. Kemudian didinginkan hingga bobot tetap.

Kadar abu $=\frac{\text { penambahan bobot }}{\text { bobot contoh }} \times 100 \%$

\section{Kandungan air (SNI 01-2973-1992)}

Ditimbang dengan timbangan Analytical balance 230 Denver sebanyak 1-2 g contoh ke dalam botol timbang yang telah diketahui bobotnya, dikeringkan dalam pengering listrik pada $105^{\circ} \mathrm{C}$, didinginkan dalam desikator Duran ID210 $\mathrm{mm}$ dan ditimbang sampai bobot tetap.

Kadar uir $=\frac{\text { hilang bobot }}{\text { bobot contoh }} \times 100 \%$

Kadar Serat Kasar (SNI 01-2973-1992)

Sampel yang telah bebas lemak ditimbang (timbangan Analytical balance 230 Denver) sebanyak 2-5 g, dimasukkan ke dalam Erlenmeyer Pyrex iwaki $750 \mathrm{ml}$. kemudian ditambahkan $100 \mathrm{ml} \mathrm{H}_{2} \mathrm{SO}_{4} \quad 1.25 \%$. Dididihkan selama 30 menit mempergunakan pendingin tegak. Kemudian ditambahkan $200 \mathrm{ml} \mathrm{NaOH} 3.25 \%$, dididihkan selama 30 menit. Dalam keadaan panas disaring ke dalam corong Buchner berisi kertas saring yang telah diketahui bobotnya (lebih dahulu dikeringkan pada $105^{\circ} \mathrm{C}$ selama $1 / 2$ jam). Dicuci berturut-turut dengan air panas, $\mathrm{H}_{2} \mathrm{SO}_{4} 1.25 \%$ air panas, alkohol $96 \%$. Kertas saring dengan isinya diangkat dan dimasukkan ke dalam cawan porselen haldenwanger yang telah diketahui bobotnya, lalu dikeringkan pada $105^{\circ} \mathrm{C}$ selama 1 jam hingga bobotnya tetap. Setelah itu cawan seisinya dilabukan dan dipijarkan, akhirnya ditimbang sampai bobot tetap.

Kadar serat kasar $=\frac{A-B-C}{\text { bobot contoh }} \times 100 \%$ 
Dimana:

A : bobot cawan + kertas saring + isi

B : bobot abu + cawan

C : bobot kertas saring

\section{Kadar karbohidrat (SNI 01-2973-1992)}

Kandungan karbohidrat dihitung menggunakan rumus:

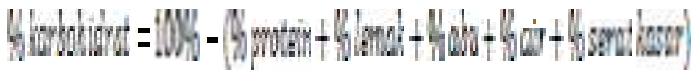

\section{HASIL DAN PEMBAHASAN}

mocaf (modified cassava flour) telah banyak dilakukan dengan cara fermentasi menggunakan starter bakteri ataupun jenis khamir dan kapang. Pada penelitian ini digunakan beberapa ragi yang budah didapatkan di pasar untuk membuat mocaf dan dilakukan analisis kadar protein, lemak, abu, air, serat kasar, karbohidrat. Selain itu juga diujikan pengaruh perendaman garam 5\% sebelum fermentasi, terhadap kadar nutrisi yang dihasilkan.

Analisis sidik ragam menunjukkan bahwa perendaman dengan garam dan jenis ragi yang Tabel 1. Kandungan Nutrisi Mocaf Hasil Fermentasi Beberapa Jenis Ragi

\begin{tabular}{|c|c|c|c|}
\hline Sampel Ragi & Protein (\%) & Lemak (\%) & Abu (\%) \\
\hline Saf Instan & $19.56^{\mathrm{b}} \pm 0.03$ & $0.35^{\mathrm{cd}} \pm 0.00$ & $0.51^{\mathrm{cd}} \pm 0.00$ \\
\hline Tempe & $34.70 f \pm 2.35$ & \pm 0.00 & $0.46 b c d \pm 0.01$ \\
\hline Tape & $34.18 f \pm 5.89$ & $0.35 \mathrm{~cd} \quad \pm 0.00$ & $0.65 \mathrm{e} \quad \pm 0.01$ \\
\hline Fermipan & $23.94 c \pm 1.08$ & $0.26 \mathrm{ab} \quad \pm 0.00$ & $0.35 \mathrm{ab} \pm 0.01$ \\
\hline Roti & $27.74 d \pm 0.62$ & $0.33 \mathrm{bcd} \pm 0.00$ & $0.46 b c d \pm 0.01$ \\
\hline Kontrol & $24.41 c \pm 3.15$ & $0.29 \mathrm{abc} \pm 0.00$ & $0.53 \mathrm{cde} \pm 0.00$ \\
\hline Saf Instan + garam & $16.29 a \pm 0.11$ & $0.31 \mathrm{abcd} \pm 0.00$ & $0.59 \mathrm{de} \pm 0.00$ \\
\hline Tempe + garam & $31.64 \mathrm{e} \pm 1.06$ & $0.37 \mathrm{~cd}$ & $0.26 \mathrm{a} \quad \pm 0.00$ \\
\hline Tape + garam & $40.86 \mathrm{~g} \pm 2.65$ & \pm 0.01 & $0.34 \mathrm{ab} \pm 0.00$ \\
\hline Fermipan + garam & $29.38 \mathrm{de} \pm 1.22$ & $0.32 \mathrm{abcd} \pm 0.00$ & $1.35 \mathrm{f}$ \\
\hline Roti + garam & $30.50 \mathrm{e} \pm 4.18$ & $0.35 \mathrm{bcd} \pm 0.00$ & $2.14 \mathrm{~g}$ \\
\hline Kontrol + garam & $18.73 b \pm 1.38$ & \pm 0.00 & $0.43 b c \pm 0.00$ \\
\hline
\end{tabular}

digunakan berpengaruh terhadap kandungan nutrisi mocaf yang dihasilkan. Pada Tabel 1 terlihat bahwa mocaf yang dihasilkan oleh fermentasi ragi tape yang didahului perendaman dengan garam memiliki kadar protein tertinggi yaitu $40,86 \%$ sedangkan yang terendah adalah mocaf yang dihasilkan oleh ragi saf instan yang didahului perendaman dengan garam, yaitu $16,29 \%$. Perendaman dengan garam ada yang meningkatkan kadar protein yang dihasilkan, yaitu pada ragi tape, fermipan dan roti, namun ada pula yang menurunkan kadar protein yaitu pada saf instan, tempe dan kontrol tanpa ragi.

Kandungan protein yang tinggi diduga karena beberapa jenis ragi ini memiliki kandungan Sacharomyces cerevisae atau Rizopus oryzae yang cukup tinggi dan mampu membuat kandungan protein meningkat. Hasil penelitian ini juga sesuai dengan penelitian yang dilakukan oleh Aida, et.al., (2012) ditemukan kandungan protein $2.121 \%$ pada perlakuan dengan S. cerevisae. 
Tabel 2. Kandungan Nutrisi Mocaf Hasil Fermentasi Beberapa Jenis Ragi

\begin{tabular}{lllll}
\hline \multicolumn{1}{c}{ Sampel Ragi } & \multicolumn{1}{c}{ Air $(\%)$} & Serat Kasar (\%) & Karbohidrat (\%) \\
\hline Saf Instan & $7.86^{\mathrm{b}} \pm 0.40$ & $3.92^{\mathrm{c}} \pm 0.45$ & $67.78^{\mathrm{g}} \pm 0.97$ \\
Tempe & $8.10 \mathrm{~b} \pm 0.75$ & $2.30 \mathrm{a} \pm 0.66$ & $53.91 \mathrm{bc} \pm 2.14$ \\
Tape & $10.72 \mathrm{~cd} \pm 0.09$ & $2.70 \mathrm{ab} \pm 0.32$ & $51.38 \mathrm{ab} \pm 5.10$ \\
Fermipan & $12.33 \mathrm{e} \pm 0.33$ & $2.20 \mathrm{a} \pm 0.20$ & $60.91 \mathrm{f} \pm 0.49$ \\
Roti & $10.65 \mathrm{c} \pm 0.80$ & $2.82 \mathrm{abc} \pm 0.69$ & $57.98 \mathrm{de} \pm 0.44$ \\
Kontrol & $11.22 \mathrm{~d} \pm 0.05$ & $3.66 \mathrm{bc} \pm 0.30$ & $59.87 \mathrm{ef} \pm 2.87$ \\
Saf Instan + garam & $8.80 \mathrm{~b} \pm 0.13$ & $2.96 \mathrm{abc} \pm 0.37$ & $71.03 \mathrm{~h} \pm 0.01$ \\
Tempe + garam & $9.82 \mathrm{c} \pm 0.01$ & $2.32 \mathrm{a} \quad \pm 0.03$ & $55.58 \mathrm{~cd} \pm 1.17$ \\
Tape + garam & $6.64 \mathrm{a} \pm 0.13$ & $2.37 \mathrm{a} \pm 1.51$ & $49.54 \mathrm{a} \pm 6.10$ \\
Fermipan + garam & $9.25 \mathrm{c} \pm 0.89$ & $2.46 \mathrm{a} \pm 0.07$ & $57.23 \mathrm{~d} \pm 2.85$ \\
Roti + garam & $8.04 \mathrm{~b} \pm 0.19$ & $2.83 \mathrm{abc} \pm 0.13$ & $56.12 \mathrm{~cd} \pm 3.55$ \\
Kontrol + garam & $10.64 \mathrm{c} \pm 0.12$ & $2.61 \mathrm{ab} \pm 0.76$ & $67.19 \mathrm{~g} \pm 3.10$ \\
\hline
\end{tabular}

Kandungan protein yang tinggi disebabkan karena kemampuan dari $S$. cerevisae maupun $R$. oryzae untuk mensekresikan beberapa enzim ekstraseluler (protein) ke dalam singkong selama proses fermentasi, atau berkembangnya $S$. cerevisae maupun $R$. oryzae ke dalam singkong dalam bentuk protein sel tunggal selama proses fermentasi (Okafor, 1998). Kadar protein yang paling tinggi didapatkan pada perlakuan fermentasi tape, diduga karena ragi yang terdapat pada tape memiliki kandungan protein yang cukup tinggi, sehingga juga didapatkan tepung mocaf yang memiliki kandungan protein yang tinggi. Menurut Penelitian Hidayati, Ba'ido dan Hastuti. 2013, pada fermentasi kulit singkong menggunakan ragi tape menemukan kandungan protein tertinggi yaitu $4,95 \%$.

Pada Tabel 1 dapat dilihat bahwa kandungan lemak yang tertinggi terdapat pada sampel ragi tempe yaitu sebesar $0.513 \%$, sedangkan yang terendah terdapat pada sampel ragi fermipan yaitu $0.265 \%$. Seperti halnya kadar protein, perendaman dengan garam tidak sama pengaruhnya terhadap setiap ragi yang digunakan, dimana untuk ragi saf instan, tempe dan tape, perendaman dengan garam meningkatkan kadar lemaknya, sementara untuk ragi roti, fermipan dan kontrol, perendaman dengan garam menurunkan kadar lemaknya.

Kadar abu tertinggi terdapat pada sampel ragi roti yang diberi perlakuan perendaman dengan garam, yaitu $2.140 \%$, sedangkan yang terendah terdapat pada ragi tempe yang diberi perlakuan perendaman dengan garam, yaitu $0.260 \%$.

Kandungan air tertinggi terdapat pada fermipan, sedangkan yang terendah terdapat pada saf instan $7.86 \%$. Pada tepung mocaf yang tanpa garam, kadar air yang dimiliki sekitar 7-12\%, sedangkan pada tepung mocaf yang diberi garam saat proses fermentasi, kadar air yang dimiliki sekitar 8-9\%, lebih rendah dibandingkan tepung mocaf yang tanpa garam. Menurut Koch dan Jane (2000), ion dari $\mathrm{NaCl}$ memiliki interaksi elektrostatik dengan air yang lebih kuat dan mendorong terjadinya ikatan hidrogen diantara molekulmolekul air. Sehingga kandungan air dalam tepung lebih rendah.

Komposisi serat kasar tertinggi pada sampel ragi saf instan yaitu 3.924\%, sedangkan yang terendah pada fermipan 2.205\%. Kandungan karbohidrat 
tertinggi terdapat pada saf instan yang diberi perlakuan perendaman dengan garam, yaitu $71.038 \%$, sedangkan yang terendah terdapat pada tape yang diberi perlakuan perendaman dengan garam, yaitu $49.548 \%$.

Dapat dilihat pada Tabel 1 dan Tabel 2, perlakuan tanpa garam, kandungan lemak, serat kasar dan air yang lebih tinggi dibandingkan pada perlakuan dengan garam. Sedangkan kandungan abu, protein dan karbohidrat lebih tinggi pada perlakuan ragi yang didahului dengan perendaman garam.

Kadar protein yang didapat setelah difermentasi dengan ragi tape yang diberi perlakuan perendaman dengan garam yaitu, sekitar 16-40\%, sedangkan dengan perendaman menggunakan ragi yang lain lebih rendah dari kadar $40 \%$. Pada penelitian Marniza, Medikasari dan Nurlaili (2011), kadar protein tepung fermentasi ubi kayu dengan menggunakan ragi tempe diperoleh kadar protein berkisar antara 2,63 11,51\%. Menurut Budiarto (2011), mikroba akan tumbuh menghasilkan enzim pektinolitik dan selulotik yang bisa memecahkan dinding sel singkong, menghasilkan pembebasan dari granula pati. Mikroba juga menghasilkan enzim yang menghidrolisis pati ke gula dan mengubahnya menjadi asam organik, terutama asam laktat.

Berdasarkan hasil penelitian dengan menggunakan perendaman ragi, hasil kadar proteinnya jauh meningkat, dan kadar air nya juga menurun. Dapat dilihat pada Tabel 1 dengan fermentasi menggunakan ragi tapai yang diberi perlakuan perendaman garam menghasilkan kadar protein mencapai $40.86 \%$, kadar karbohidrat $49.58 \%$, kadar serat kasar $2,70 \%$ dan kadar air menurun sampai $6.64 \%$. Sedangkan pada hasil tepung ubi kayu tanpa perendaman dengan ragi fermentasi, kadar protein $24,41 \%$, kadar karbohidrat
$59,87 \%$, kadar serat kasar 3,66\% dan kadar air 11,22\%. Menurut Badan Penelitian dan Pengembangan Pertanian (2011), singkong segar mempunyai komposisi kimiawi terdiri dari kadar air sekitar $60 \%$, pati $35 \%$, serat kasar 2,5\% dan kadar protein $1 \%$. Terlihat bahwa fermentasi dapat meningkatkan kadar protein pada mocaf.

Jumlah mocaf yang dihasilkan paling tinggi adalah mocaf yang dibuat dengan fermentasi menggunakan fermipan dan didahului dengan perendaman dengan garam $5 \%$, yaitu 206.54 gram lebih banyak dibandingkan kontrol tanpa fermentasi yaitu 196.92 gram. Sementara perlakuan yang lain menghasilkan mocaf dengan jumlah yang lebih sedikit. Hal ini mungkin disebabkan karena pati singkong dipakai oleh mikroorganisme pada ragi sebagai nutrisi, selain kadar air singkong yang menguap selama pengeringan tepung. Pada saat fermentasi dengan fermipan dan ragi roti, chip singkong menjadi hancur oleh mikroorganisme, sehingga banyak yang terbuang selama pencucian.

\section{KESIMPULAN}

Mocaf terbaik yang dihasilkan pada penelitian ini adalah mocaf yang dibuat dari fermentasi menggunakan ragi tape yang diawali perendaman dengan garam, karena menghasilkan mocaf dengan kadar protein yang paling tinggi yaitu $40.860 \%$, dengan kadar air rendah $6.640 \%$.

\section{UCAPAN TERIMA KASIH}

Penulis mengucapkan terima kasih kepada Direktorat Jenderal Perguruan Tinggi (DIKTI), Koordinator Kopertis Wilayah X, Ketua STKIP PGRI Sumatera Barat, Kepala UPPPM STKIP PGRI Sumatera Barat, dan Pimpinan Program Studi Pendidikan Biologi STKIP PGRI Sumatera Barat. 


\section{DAFTAR RUJUKAN}

Aida N, Kurniati NI dan Gunawan S. 2012. Pembuatan Mocaf (Modified Cassava Flour) dengan Proses Fermentasi Menggunakan Rhizopus oryzae dan Saccharomyces cerevisae. Seminar Nasional Teknik Kimia Soebardjo Brotohardjono XI. Surabaya. 21 Jun 2012. P: D2.1-D2.5

Badan Penelitian dan Pengembangan Pertanian. 2011. Inovasi Pengolahan Singkong Meningkatkan Pendapatan Dan Diversifikasi Pangan. www.litbang.deptan.go.id. P: 1 - 5

Budiarto. 2011. Opportunity of Modified Cassava Flour (MOCAF) as Wheat Flour Substitute an Alternative Materials to Support Food Security. ISNAR C2FS PROCEEDING 837. Natural Resources Climate Change and Foot Security in Developing Countries. Surabaya, Indonesia, June 27 - 28, 2011.

Cardosoa AP, Mirioneb E, Ernestob M, Massazab F, Cliffc J, Haquee MQ, and Bradburye HJ. 2005. Processing Of Cassava Roots To Remove Cyanogens. Journal of Food Composition and Analysis 18: 451- 460 .

Darmawan RM, Andreas P, Jos B, Sumardiono S. 2013. Modifikasi Ubi Kayu Dengan Proses Fermentasi Menggunakan Starter Lactobcillus casei Untuk Produk Pangan. Jurnal Teknologi Kimia dan Industri, Vol.2 No.4: 137 145

Dewi RK. 2012. Rekayasa Beras Analog Berbahan Dasar Modified Cassava
Flour (MOCAF) dengan

Teknologi Ekstruksi. [Skripsi]. Bogor: Fakultas Teknologi Pertanian. Institut Pertanian Bogor.

Hidayati D, B'ido D, Hastuti S. 2013. Pola Pertumbuhan ragi Tape Pada Fermentasi Kulit Singkong. AGROINTEK Vol. 7 No.1: 6 - 10

Kusumawardhani D. 2012. Nasionalisme Ketahanan Pangan Melalui IPTEKDALIPI. IPTEKDA LIPI. Jakarta.

Marniza, Medikasari dan Nurlaili. 2011. Produksi tepung ubi kayu berprotein: kajian pemanfaatan Tepung kacang benguk sebagai sumber nitrogen ragi tempe. Jurnal Teknologi dan Industri Hasil Pertanian Vol. 16 No.1: 73 - 81

Okafor. 1998. An integrated bio-system for the disposal of cassava wastes, integrated bio-systems in zero emissions applications. In Proceeding of the Internet Conference on Integrated BioSystems. Available: http://www.ias.unu.edu/proceedin gs/icibs. P: 1 - 6

Romadhanty FD. 2011. Analisis Penerimaan Teknis, Benefit cost Ratio dan Preferensi Konsumen terhadap Beberapa Kombinasi Tepung Terigu dengan MOCAF pada Produksi Roti Tawar (Studi Kasus pada PD Galuh Sari, Bogor). [Skripsi] Bogor: Fakultas Ekonomi dan Manajemen. Institut Pertanian Bogor.

Rosmeri IV. dan Monica NB. 2013. Pemanfaatan Tepung Umbi Gadung (Dioscorea hispida Dennst) dan Tepung MOCAf 
(Modified Cassava Flour) Sebagai

Bahan Substitusi dalam

Pembuatan Mie Basah, Mie

Kering dan Mie Instan. Jurnal

Teknologi Kimia dan Industri

Vol.2 No. 2: 246 - 256

Salim E. 2011. Mengolah Singkong

Menjadi Tepung Mocaf. P: 4 - 55.

Lily Publisher. Yogyakarta.

Sukoco HD. 2013. Pengaruh Subtitusi

Tepung MOCAF (modified cassava flour) dan Penambahan Puree Wortel (Daucus carota) terhadap sifat organoleptik mie telur. E- Journal Boga. Vol. 02. No. 3: $25-33$

Yenrina, Surya, dan Putri. 2013. Mocaf bread enriched with Mung Bean (Vigna radiata L.) as a source of protein. Asia Pacific Journal of Sustainable Agriculture Food and Energy (APJSAFE). Vol. 1. No.1: $10-13$. 